Original article

\title{
Expression of common fragile sites in two Ceboidea species: Saimiri boliviensis and Alouatta cara a (Primates: Platyrrhini)
}

\author{
Ariela Fundia* ${ }^{\mathrm{a}}$, María Gorostiaga ${ }^{\mathrm{b}}$, Marta MudrY ${ }^{\mathrm{b}}$ \\ a Department of Genetics, Hematology Research Institute, "Mariano R. Castex", \\ National Academy of Medicine, Pacheco de Melo 3081, C.P. 1425, Buenos Aires, \\ Argentina \\ b Department of Biology (GIBE), FCEyN, Buenos Aires University, \\ Buenos Aires, Argentina
}

(Received 7 September 1998; accepted 22 November 1999)

\begin{abstract}
Fragile sites are points of preferential breakage that may be involved in chromosome rearrangements. Induction of common fragile sites (c-fra) and spontaneous breakage were analyzed in two New World Monkeys species: Saimiri boliviensis (SBO) and Alouatta caraya (ACA). Spontaneous chromosome aberrations were analyzed on untreated lymphocyte cultures with Brögger's formula (1977). SBO presented a low level of spontaneous breakage, while higher frequencies were detected in ACA in which bands 1q23; 2q13 and 11q19 were significantly affected $(p<0.01)$. The populational distribution of c-fra was analyzed by the $\mathrm{Chi}^{2}$ test in FUdR plus caffeine treated cultures. A total of $21 \mathrm{c}$-fra was identified in SBO and 24 in ACA. Fragile sites $\mathrm{A}_{1} \mathrm{q} 33, \mathrm{~B}_{1} \mathrm{p} 21, \mathrm{~B}_{4} \mathrm{p} 14, \mathrm{C}_{3} \mathrm{q} 23$ and $\mathrm{C}_{5} \mathrm{q} 22$ were identified in all analyzed SBO specimens. The most frequent c-fra identified in ACA specimens were 1q23, 1q31, 1q33, 2q22, 8q14, 12q31, 13q22, 14q15 and Xq22. Fragile sites $A_{1} q 31, A_{1} q 33, B_{1} q 14$, $\mathrm{B}_{3} \mathrm{q} 13, \mathrm{~B}_{4} \mathrm{q} 21$ and Xq22 identified in SBO and $1 \mathrm{q} 31,1 \mathrm{q} 33,2 \mathrm{q} 22,4 \mathrm{q} 21,6 \mathrm{q} 13,13 \mathrm{q} 22$ and $\mathrm{Xq} 22$ from ACA were the most conserved sites. A low coincidence between the location of c-fra and that of heterochromatin and breakpoints involved in euchromatic rearrangements known for these genera, was established.
\end{abstract}

Ceboidea / fragile sites / chromosomal rearrangements / heterochromatin / evolution

Résumé - Sites communs de fragilité chromosomique chez deux espèces de Ceboïdés : Saimiri boliviensis et Alouatta cara a (Primates : Platyrrhini). Les sites fragiles sont des régions de cassure préférentielle, dans le génome, qui peuvent être associées à des remaniements chromosomiques. On a étudié les sites communs fragiles (c-fra) et les cassures spontanées dans deux genres de primates du Nouveau Monde : Saimiri boliviensis (SBO) et Alouatta caraya (ACA). Les cassures spontanées

* Correspondence and reprints

E-mail: lacuteci@intramed.net.ar 
ont été étudiées avec la formule de Brögger (1977) sur des cultures de lymphocytes non traités. Alors que SBO présente très peu de cassures spontanées, celles-ci sont fréquentes chez $\mathrm{ACA}$, où trois bandes : 1q23, 2q13 et 11q19 sont significativement affectées $(p<0,01)$. La distribution spécifique des c-fra a été analysée par le test $\mathrm{du} \mathrm{Chi}^{2}$ dans des cultures traitées par le FUdR et la caféine. Un total de $21 \mathrm{c}$-fra chez SBO et 24 chez ACA a été observé. Les c-fra $\mathrm{A}_{1} \mathrm{q} 33, \mathrm{~B}_{1} \mathrm{p} 21, \mathrm{~B}_{4} \mathrm{p} 14, \mathrm{C}_{3} \mathrm{q} 23$ et $\mathrm{C}_{5} \mathrm{q} 22$ ont été identifiés dans tous les spécimens SBO. Les c-fra les plus fréquents identifiés chez ACA sont 1q23, 1q31, 1q33, 2q22, 8q14, 12q31, 13q22, 14q15 et Xq22. Les c-fra les plus conservés chez SBO sont $\mathrm{A}_{1} \mathrm{q} 31, \mathrm{~A}_{1} \mathrm{q} 33, \mathrm{~B}_{1} \mathrm{q} 14, \mathrm{~B}_{3} \mathrm{q} 13, \mathrm{~B}_{4} \mathrm{q} 21$ et Xq22 et chez ACA 1q31, 1q33, 2q22, 4q21, 6q13, 13q22 et Xq22. Nous avons établi une faible coïncidence entre l'emplacement des c-fra et celui de l'hétérochromatine et des cassures impliquées dans les remaniements de l'euchromatine connus dans ces genres.

Ceboidea / sites fragiles / remaniements chromosomiques / hétérochromatine / évolution

\section{INTRODUCTION}

Chromosomal fragile sites are points on chromosomes which show nonrandom gaps or breaks under specific conditions. They are classified as rare (carried by few individuals) or common (virtually in all individuals) and are subdivided according to the conditions used for their induction. Rare folate sensitive fragile sites are expansions (dynamic mutations) of CCG-repeat sequences. Rare FRA16B and FRA10B sites are expansions of very AT-rich minisatellites. In contrast, sequence data for common sites show no striking features such as trinucleotide or minisatellite repeats [63]. These sites have been shown to display a number of characteristics of unstable and highly recombinogenic DNA in vitro, including chromosome rearrangements, sister chromatid exchanges and intrachromosomal gene amplifications [26]. Although there has been substantial advancement in the study of their molecular structure, the potential for a relationship with disease is still unknown except for the association with mental retardation (fragile $X$ syndrome) [63]. Autosomal fragile sites have been related to the origin of constitutional or cancer rearrangements [23, $33,49,61,63]$ and they can be targets of mutagens and carcinogens $[2,3,71]$. They have also been associated with chromosomal changes during evolution $[6$, 28, 31, 38, 39].

Examples of chromosomal variation are common in primate speciation $[6$, 13, 65], pericentric inversions and heterochromatic block variations being more frequently observed [48]. Chromosome comparison using banding methods and in situ hybridization has demonstrated that human chromosomes show a high homology with some Platyrrhini species [7-9, 43, 53] as well as other anthropoid species [6, 48, 57] and other mammals [68]. Taking into account that chromosomal rearrangements could be incorporated in the course of the evolutionary process, comparative cytogenetics has been used in phylogenetic studies $[6,8$, 13, 51]. Considering that common fragile sites (c-fra) are reliable markers of genetic instability [24], fragile site studies provide a widely applicable means to evaluate the change in chromosome structure and its possible implications in speciation. In the present work, we provide new evidence on primate chromosome variability, evaluating spontaneous breakage and distribution of common fragile sites in two Ceboidea species. 


\section{MATERIALS AND METHODS}

C-fra expression was analyzed in heparinized peripheral blood samples from 16 specimens: 12 ACA and 4 SBO. Two cultures were set up simultaneously for each specimen in F10 medium with phytohemagglutinin $M\left(0.1 \mu \mathrm{g} \cdot \mathrm{mL}^{-1}\right.$, SIGMA) and fetal bovine serum $\left(5 \%\right.$, GIBCO) for $72 \mathrm{~h}$ at $37^{\circ} \mathrm{C}$. Spontaneous breakage was analyzed in an untreated culture (control) and fragile sites were induced by known fragile site inducers such as fluorodeoxyuridine (FUdR) $\left(10 \mu \mathrm{g} \cdot \mathrm{mL}^{-1}\right)$ for the final $24 \mathrm{~h}$ of culture [20] and caffeine $(2.2 \mathrm{mM})$ for the last $6 \mathrm{~h}[70]$.

Cells were routinely harvested and 25 to 70 Giemsa stained metaphases were analyzed on coded slides to record the presence of chromosome aberrations (CA), following the "International System for Human Cytogenetic Nomenclature" [29]. Slides with abnormal cells were destained and re-analyzed after sequential G-banding [59] to identify the breakpoints involved in CA. The karyotype of each species was considered following previously published works [21, 22, 25, 45-47]. Spontaneous CA were analyzed with Brögger's formula (1977) [4], and fragile sites were defined by the Chi2 test with Yates correction [27]. A haploid karyotype was considered for both statistical analyses assuming that all bands had an equal probability of breakage.

\section{RESULTS}

The most frequent CAs observed were gaps and breaks, while a low proportion of acentric fragments or triradial figures was only found in treated cultures. Chromosome or chromatid gaps, breaks and acentric fragments were scored as single chromosome events and dicentric or triradial configurations as two chromosome events. G-band analysis of control cultures allowed the identification of 6 and 39 spontaneous CAs in SBO and ACA specimens, respectively. Based on a SBO haploid karyotype of 257 bands [25, 46], statistical analysis with Brögger's formula showed that any band with 2 or more lesions was nonrandomly damaged $(p<0.0005)$. Since these six aberrations were located on different bands, no bands significantly involved in spontaneous breakage were found in SBO. On the other hand, spontaneous breakage analysis in ACA considering a haploid karyotype of 287 bands [21, 22, 46, 47] demonstrated that any band with 2 or more lesions was non-randomly damaged $(p<0.01)$, identifying 3 bands: 1q23, 2q13 and 11q19 which were hot-spots for spontaneous breakage.

A total of 245 and 328 CAs was identified with sequential G-banding in SBO and ACA treated cultures, respectively. Based on a SBO haploid karyotype, the expected number of breaks per band for the 245 observed aberrations is 0.95 . $\mathrm{Chi}^{2}$ analysis showed that any band with five or more lesions is non-randomly damaged in excess $(p<0.001)$, indicating 21 induced fragile sites (Tab. I). The expression frequencies of these fragile sites confirmed that all sites were common (c-fra). Five of the 21 fragile sites (24\%), located at $\mathrm{A}_{1} \mathrm{q} 33, \mathrm{~B}_{1} \mathrm{p} 21$, $\mathrm{B}_{4} \mathrm{p} 14, \mathrm{C}_{3} \mathrm{q} 23$ and $\mathrm{C}_{5} \mathrm{q} 22$ were identified in all SBO specimens, 13 sites $(62 \%)$ were induced in 3 specimens and only 3 sites (14\%) were detected in 2 specimens. SBO specimens exhibited 13 to 19 of the 21 c-fra (Tab. I). Some of these fragile sites are shown in Figure 1. Based on an ACA haploid karyotype, 
Table I. Numbers of chromosome aberrations and common fragile sites induced in Saimiri boliviensis.

\begin{tabular}{|c|c|c|c|c|c|}
\hline \multirow{2}{*}{$\begin{array}{l}\text { Common } \\
\text { Fragile sites }\end{array}$} & \multicolumn{5}{|c|}{ Chromosome aberrations in each specimen } \\
\hline & 1 & 2 & 3 & 4 & Total \\
\hline $\mathrm{A}_{1} \mathrm{q} 21$ & 2 & 0 & 3 & 4 & 9 \\
\hline $\mathrm{A}_{1} \mathrm{q} 31$ & 3 & 1 & 1 & 0 & 5 \\
\hline $\mathrm{A}_{1} \mathrm{q} 33$ & 1 & 1 & 1 & 2 & 5 \\
\hline $\mathrm{A}_{1} \mathrm{q} 35$ & 2 & 0 & 2 & 1 & 5 \\
\hline $\mathrm{A}_{2} \mathrm{q} 12$ & 3 & 5 & 1 & 0 & 9 \\
\hline $\mathrm{B}_{1} \mathrm{p} 21$ & 4 & 3 & 1 & 1 & 9 \\
\hline $\mathrm{B}_{1} \mathrm{q} 14$ & 5 & 4 & 0 & 1 & 10 \\
\hline $\mathrm{B}_{1} \mathrm{q} 23$ & 1 & 0 & 3 & 1 & 5 \\
\hline $\mathrm{B}_{2} \mathrm{q} 21$ & 0 & 0 & 2 & 3 & 5 \\
\hline $\mathrm{B}_{2} \mathrm{q} 23$ & 0 & 2 & 3 & 0 & 5 \\
\hline $\mathrm{B}_{2} \mathrm{q} 31$ & 3 & 2 & 3 & 0 & 8 \\
\hline $\mathrm{B}_{2} \mathrm{q} 33$ & 5 & 6 & 0 & 1 & 12 \\
\hline $\mathrm{B}_{3} \mathrm{q} 13$ & 4 & 2 & 1 & 0 & 7 \\
\hline $\mathrm{B}_{3} \mathrm{q} 15$ & 3 & 2 & 1 & 0 & 6 \\
\hline $\mathrm{B}_{4} \mathrm{p} 14$ & 1 & 2 & 1 & 1 & 5 \\
\hline $\mathrm{B}_{4} \mathrm{q} 21$ & 4 & 0 & 4 & 1 & 9 \\
\hline $\mathrm{B}_{4} \mathrm{q} 23$ & 3 & 2 & 3 & 0 & 9 \\
\hline $\mathrm{C}_{3} \mathrm{q} 23$ & 5 & 1 & 1 & 1 & 8 \\
\hline $\mathrm{C}_{3} \mathrm{q} 25$ & 2 & 2 & 0 & 1 & 5 \\
\hline $\mathrm{C}_{5} \mathrm{q} 22$ & 2 & 2 & 1 & 1 & 6 \\
\hline $\mathrm{Xq} 22$ & 4 & 1 & 0 & 0 & 5 \\
\hline Total number of c-fra & 57 & 38 & 32 & 19 & 146 \\
\hline Number of CA recorded & 84 & 74 & 56 & 31 & 245 \\
\hline Number of cells analyzed & 70 & 50 & 50 & 50 & 220 \\
\hline Number of abnormal cells & 50 & 36 & 29 & 20 & 135 \\
\hline
\end{tabular}
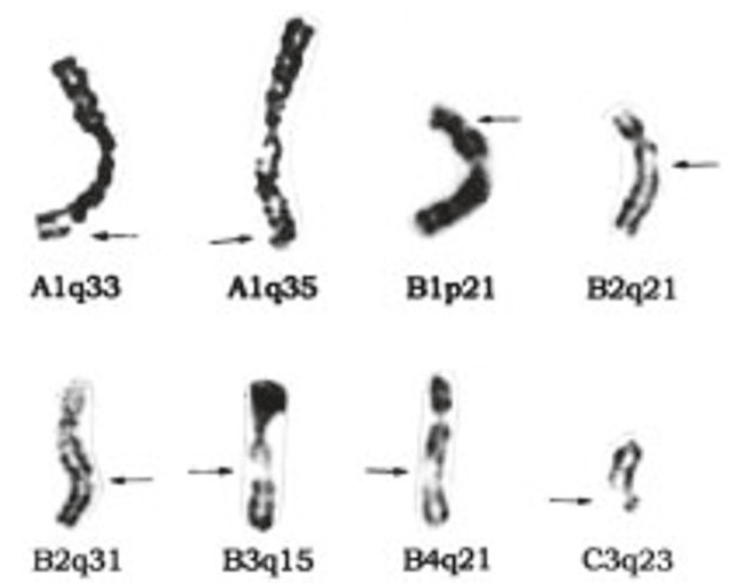

Figure 1. G-banded chromosomes showing fragile sites $(\rightarrow)$ induced in SBO specimens. 
the expected number of breaks per band for the 328 aberrations observed is 1.14. Statistical analysis showed that any band with five or more lesions is significantly damaged $(p<0.005)$, identifying 24 c-fra (Tab. II). Fourteen out of 24 c-fra were fragile in $50-83 \%$ of the ACA population. The most frequent fragile site was $2 \mathrm{q} 22$ (Fig. 2) expressed in 10 specimens (83\%), while 4q21, 9p13, 9q13, 11q13 and 15q21 were observed in only six specimens (50\%). ACA specimens exhibited 5 to 19 of the 24 fragile sites.

Locations of fragile sites were compared with heterochromatic regions and breakpoints involved in euchromatic rearrangements known at present. No chromosome rearrangements were found in the SBO specimens presently analyzed nor in our previous studies with different specimens. A heterochromatic polymorphism at chromosome $\mathrm{B}_{11} \mathrm{p} 14$ was observed in these specimens, but no fragile sites were found at this site. Only $3 / 21(14 \%)$ of the c-fra sites $\left(\mathrm{B}_{1} \mathrm{q} 14\right.$, $\left.\mathrm{B}_{1} \mathrm{q} 23, \mathrm{~B}_{4} \mathrm{p} 14\right)$ coincided with $\mathrm{C}$-bands in SBO. No relationship between

Table II. Numbers of chromosome aberrations and common fragile sites induced in Alouatta caraya.

\begin{tabular}{|c|c|c|c|c|c|c|c|c|c|c|c|c|c|}
\hline \multirow{2}{*}{$\begin{array}{l}\text { Common } \\
\text { Fragile sites }\end{array}$} & \multicolumn{13}{|c|}{ Chromosome aberrations in each specimen } \\
\hline & 1 & 2 & 3 & 4 & 5 & 6 & 7 & 8 & 9 & 10 & 11 & 12 & Total \\
\hline $1 \mathrm{q} 13$ & 0 & 0 & 0 & 0 & 1 & 0 & 0 & 0 & 1 & 3 & 0 & 1 & 6 \\
\hline $1 \mathrm{q} 23$ & 1 & 0 & 0 & 2 & 2 & 1 & 0 & 1 & 1 & 1 & 1 & 5 & 15 \\
\hline $1 \mathrm{q} 31$ & 2 & 1 & 0 & 2 & 0 & 1 & 0 & 2 & 0 & 2 & 0 & 2 & 12 \\
\hline $1 \mathrm{q} 33$ & 1 & 0 & 0 & 4 & 0 & 0 & 0 & 1 & 1 & 1 & 1 & 1 & 10 \\
\hline $2 \mathrm{q} 13$ & 0 & 0 & 0 & 1 & 0 & 2 & 0 & 1 & 0 & 1 & 5 & 0 & 10 \\
\hline $2 \mathrm{q} 22$ & 1 & 1 & 1 & 1 & 3 & 2 & 0 & 1 & 1 & 2 & 0 & 1 & 14 \\
\hline $2 q 36$ & 0 & 0 & 0 & 1 & 0 & 0 & 0 & 2 & 0 & 0 & 0 & 2 & 5 \\
\hline $3 \mathrm{q} 31$ & 0 & 0 & 0 & 2 & 0 & 0 & 1 & 1 & 1 & 0 & 0 & 1 & 6 \\
\hline $4 q 21$ & 0 & 0 & 1 & 1 & 0 & 0 & 1 & 1 & 0 & 1 & 0 & 1 & 6 \\
\hline 6q13 & 0 & 1 & 0 & 0 & 0 & 2 & 0 & 0 & 1 & 0 & 2 & 1 & 7 \\
\hline $8 q 14$ & 1 & 3 & 0 & 2 & 0 & 2 & 2 & 1 & 0 & 0 & 3 & 5 & 19 \\
\hline 9p13 & 1 & 2 & 0 & 1 & 0 & 0 & 0 & 0 & 0 & 1 & 3 & 2 & 10 \\
\hline 9q13 & 3 & 1 & 0 & 2 & 0 & 2 & 0 & 0 & 1 & 1 & 0 & 0 & 10 \\
\hline $11 q 13$ & 1 & 0 & 0 & 0 & 1 & 3 & 0 & 1 & 0 & 0 & 1 & 1 & 8 \\
\hline $11 q 19$ & 1 & 0 & 0 & 0 & 2 & 0 & 1 & 1 & 0 & 0 & 0 & 1 & 6 \\
\hline $11 \mathrm{q} 23$ & 0 & 0 & 0 & 0 & 0 & 1 & 0 & 1 & 0 & 1 & 0 & 3 & 6 \\
\hline $12 \mathrm{q} 31$ & 1 & 1 & 0 & 3 & 0 & 0 & 1 & 0 & 2 & 1 & 0 & 1 & 10 \\
\hline $13 q 13$ & 0 & 0 & 1 & 1 & 0 & 1 & 0 & 0 & 2 & 1 & 0 & 0 & 6 \\
\hline $13 \mathrm{q} 22$ & 1 & 0 & 0 & 2 & 1 & 0 & 0 & 1 & 1 & 2 & 0 & 2 & 10 \\
\hline $13 \mathrm{q} 24$ & 0 & 0 & 0 & 0 & 0 & 0 & 1 & 0 & 1 & 0 & 2 & 1 & 5 \\
\hline $14 \mathrm{q} 15$ & 0 & 0 & 1 & 1 & 0 & 1 & 1 & 1 & 0 & 1 & 0 & 1 & 7 \\
\hline $15 \mathrm{q} 21$ & 0 & 1 & 0 & 1 & 1 & 1 & 0 & 0 & 0 & 2 & 1 & 0 & 7 \\
\hline $16 q 13$ & 0 & 2 & 0 & 0 & 1 & 0 & 0 & 1 & 0 & 0 & 1 & 1 & 6 \\
\hline $\mathrm{Xq} 22$ & 1 & 0 & 1 & 2 & 2 & 1 & 1 & 0 & 1 & 1 & 0 & 1 & 11 \\
\hline Total number of c-fra & 15 & 13 & 5 & 29 & 14 & 20 & 9 & 17 & 14 & 22 & 20 & 34 & 212 \\
\hline Number of CA recorded & 26 & 24 & 14 & 41 & 20 & 26 & 17 & 28 & 20 & 25 & 34 & 53 & 328 \\
\hline Number of cells analyzed & 25 & 25 & 25 & 50 & 50 & 50 & 25 & 25 & 25 & 25 & 25 & 50 & 400 \\
\hline Number of abnormal cells & 14 & 16 & 12 & 14 & 16 & 27 & 17 & 18 & 18 & 17 & 16 & 38 & 223 \\
\hline
\end{tabular}



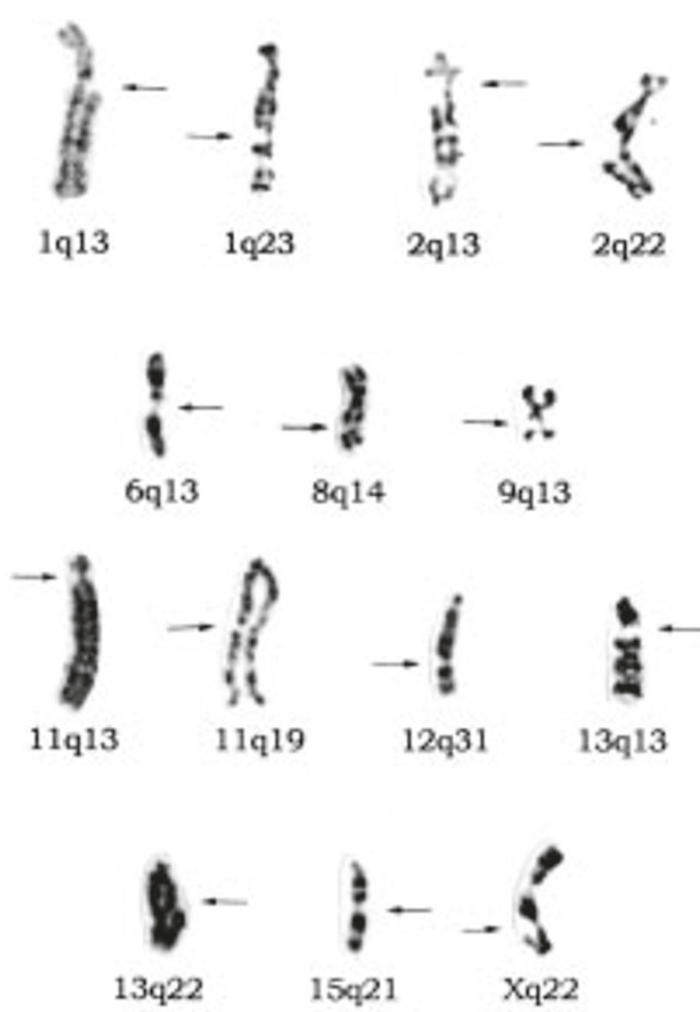

Figure 2. G-banded chromosomes showing fragile sites $(\rightarrow)$ induced in ACA specimens.

induced c-fra sites and chromosomal changes known in SBO was found. In ACA, a particular sex determination system was observed, resulting from a reciprocal translocation $t(7 ; Y)$, but no heterochromatic region or fragile site were observed on these chromosomes. Only c-fra 1q31 from ACA coincided with a breakpoint involved in a pericentric inversion proposed by Mudry et al. [43], demonstrating a low coincidence $(1 / 24,4 \%)$ with rearranged sites. Considering the total number of fragile sites identified in each species, no significant correlation was found between heterochromatic regions or structural changes and fragile sites.

\section{DISCUSSION}

It has been suggested that fragile sites are regions susceptible to breakage and rearrangements that could be involved in chromosome evolution. Many reports have established a theoretical correlation between the location of human fragile sites and bands involved in rearrangements during primate chromosomal evolution $[5,6,39,60]$. The possible mechanisms and pathway of karyotype evolution in primates have been extensively discussed [12, 13, 47, 52]. The immense variety of karyotypes of extant forms provides suggestive evidence that chromosome change has played and continues to play a major role in 
evolution [11, 12, 14-16, 30]. What is the relationship between chromosome change and evolutionary change? The ability to determine accurately the type and number of rearrangements is a critical step in understanding chromosomal evolution [1].

Spontaneous breakage has rarely been described in the karyotypes of primates up to now and to our knowledge there are no other reports of spontaneous chromosome fragility in different Ceboidea species. A low frequency of spontaneous CA was found in SBO specimens (6\%), while ACA presented higher levels (30\%). Different frequencies of spontaneous breakage have been previously reported in other mammals, ranging from as few as $8 \%$ to as many $64 \%[2,3,38,60,69]$. In addition, three spontaneous fragile sites, coincident with induced ones, were found to be significantly damaged in ACA, suggesting that these areas are more susceptible to chromosomal breakage. The specific involvement of certain bands in spontaneous breakage from New World Monkeys provides new evidence for the particular variability of the Ceboidea genome.

Relatively few reports have been published on induction of fragile sites in species other than man $[17,18,34,38,54-56,62,64]$. C-fra induction was reported in a few neotropical primates: Cebus apella [19, 41] and Alouatta caraya [21]. Induction of fragile sites was also described in gorilla, chimpanzee and orangutan, showing an evolutionary conservation of these sites between the Great Apes and man and suggesting that fragile sites have been highly conserved during primate evolution $[58,60,70]$. In order to analyze the conservation of fragile sites in Ceboidea, the present data were compared to previous results on Cebus apella paraguayanus (CAP) chromosomes identifying 11 induced fragile sites (2q13, 2q26, 3q31, 5q22, 6q21, 11q15, 12q22, 19q13, 19q22, 20q13 and Xq22) [22, 46]. Taking into account the chromosome homologies previously described in SBO, ACA and CAP [43], a homologous c-fra at band Xq22 was observed in all three species. This finding is in agreement with the well-known conservation of the $\mathrm{X}$ chromosome $[12,43,57,67,68]$. The three species also conserved a c-fra at bands $3 \mathrm{q} 31$ from CAP, $\mathrm{B}_{1} \mathrm{q} 14$ from SBO and $2 \mathrm{q} 22$ from ACA. C-fra $\mathrm{A}_{1} \mathrm{q} 31, \mathrm{~A}_{1} \mathrm{q} 33, \mathrm{~B}_{3} \mathrm{q} 13$ and $\mathrm{B}_{4} \mathrm{q} 21$ from SBO were homologous to c-fra 1q31, 1q33, 6q13 and 4q21 from ACA, respectively. C-fra 20q13 from CAP was homologous to 13q22 from ACA. These data are in agreement with our previous data on the variability of Ceboidea karyotypes $[25,43-47,50,52]$ and on those reported by other authors [9-11, 36].

It has been proposed that interbands between euchromatic and heterochromatic regions are probably more susceptible to breakage [66]. A poor relationship was established between fragile site location and heterochromatic regions or breakpoints involved in euchromatic rearrangements known for CAP, SBO and ACA $[5,25,32,35-37,40,42,43,47,52]$. Three CAP c-fra sites (6q21, $11 q 15$ and 12q22) coincide with heterochromatic bands. One of them, 12q22, is associated with a paracentric inversion involving the heterochromatic region observed in different Cebus apella ssp (Mudry, unpublished data), also reported for other heterochromatic regions [50]. Another c-fra, 11q15, coincides with a terminal deletion of a C-band in C. a. nigritus [44] and paracentric inversions observed in C. a. robustus and C. a. xanthosternos [37]. Three SBO c-fra sites $\left(\mathrm{B}_{1} \mathrm{q} 14, \mathrm{~B}_{1} \mathrm{q} 23, \mathrm{~B}_{4} \mathrm{p} 14\right)$ are located at C-bands. Only one ACA c-fra (1q31) is located at a breakpoint of a pericentric inversion involved in the evolution of the Ceboidea karyotype [43]. Smeets and Klundert induced fragile site expression on 
chromosomes of the Great Apes and showed that 35\% of fragile sites coincided with rearranged sites in primates [60]. In addition, a theoretical relationship was found between breakpoints in Ceboidea and human fragile sites, suggesting that the location of latent centromeres in Platyrrhini and heterochromatic regions were related [5]. Our results demonstrate that no important correlation exists between heterochromatin or structural changes and fragile sites induced in these Ceboidea species. In fact, to clarify the role of fragile sites in karyological evolution, it will be important to identify more fragile sites in a great number of individuals from different species, characterize chromosomal homologies between these species, identify more chromosome rearrangements involved in evolutionary pathways, map the breakpoints and compare them to fragile site locations.

\section{ACKNOWLEDGEMENTS}

We thank J. Ruiz for supplying SBO blood samples from CAPRIM (Argentine Primate Center); Dr. G. Zunino for his valuable work in the Argentinean forest supplying ACA and CAP samples; Lic. A. Delprat for her help with karyotype preparations; Mr. E. Crocitto and R. Fraiman for their photographic work. This publication was produced during the UBACYT EX 288 Project.

\section{REFERENCES}

[1] Baker R.J., Qumsiyeh M.B., Hood C.S., Role of chromosomal banding patterns in understanding mammalian evolution, in: Genoways H.H. (Ed.), Current mammalogy, Plenum Publishing Co., 1987, Vol. 1, Chap. 2, pp. 67-96.

[2] Borrell A., Ponsà M., Egozcue J., Rubio A., García M., Chromosome abnormalities in peripheral blood lymphocytes from Cebus apella (Cebidae, Platyrrhini) after X-ray irradiation, Mutat. Res. 401 (1998) 65-76.

[3] Borrell A., Ponsà M., Egozcue J., Rubio A., García M., Chromosome abnormalities in peripheral blood lymphocytes from Macaca fascicularis and Erythrocebus patas (Cercopithecidae, Catarrhini) after X-ray irradiation, Mutat. Res. 403 (1998) $185-198$.

[4] Brögger A., Non random localization of chromosomal damage in human cells and target for clastogenic action, Chromosome Today, Vol. 6, de la Chapelle A., Sorsa M. Eds., Elsevier/North-Holland Biomedical Press, Amsterdam, The Netherlands, 1977, pp. 297-306.

[5] Clemente I.C., García M., Ponsà M., Egozcue J., High-resolution chromosome banding studies in Cebus apella, Cebus albifrons and Lagothrix lagothricha: comparison with the human karyotype, Am. J. Primatol. 13 (1987) 23-26.

[6] Clemente I.C., García M., Ponsà M., Egozcue J., Evolution of the Simiiformes and the phylogeny of human chromosomes, Hum. Genet. 84 (1990) 493-506.

[7] Consigliere S., Stanyon R., Koehler U., Agoramoorthy G., Wienberg J., Chromosome painting defines genomic rearrangements between red howler monkey subspecies, Chromosome Research 4 (1996) 264-270.

[8] Consigliere S., Stanyon R., Koehler U., Arnold N., Wienberg J., In situ hybridization (FISH) maps chromosomal homologies between Alouatta belzebul (Platyrrhini, Cebidae) and other primates and reveals extensive interchromosomal rearrangements between Howler Monkeys genomes, Am. J. Primatol. 46 (1998) 119133. 
[9] Dutrillaux B., Very large analogy of chromosome banding between Cebus capucinus (Platyrrhini) and man, Cytogenet. Cell Genet. 24 (1979) 84-94.

[10] Dutrillaux B., Chromosomal evolution in Primates: Tentative phylogeny from Microcebus murinus (Prosimian) to man, Human Genetics 48 (1979) 251-314.

[11] Dutrillaux B., Le rôle des chromosomes dans l'évolution : une nouvelle interprétation, Ann. Génét. 29 (1986) 69-75.

[12] Dutrillaux B., Como evolucionan los cromosomas de los mamíferos, Mundo Científico 179 (1997) 460-465.

[13] Dutrillaux B., Richard F., Nuestro nuevo árbol de familia, Mundo Científico 181 (1997) 646-655.

[14] Dutrillaux B., Couturier J., Muleris M., Rumpler B., Viegas-Pequignot E., Relations chromosomiques entre sous-ordres et infraordres, et schéma évolutif général des Primates, Mammalia 50 (1986) 108-121.

[15] Eberle P., Chromosome finds in primates and cytogenetical aspects in the evolution of man, J. Human Evol. 4 (1975) 435-439.

[16] Egozcue J., Chordata 4, Mammalia II: Placentalia 5, Primates, in: John B., Bauer H., Brown S., Kayano H., Levan A., White M. (Eds.), Monographs on animal cytogenetics, Borntraeger, Stuttgart, 1975.

[17] Elder F.F.B., Robinson T.J., Rodent common fragile sites: are they conserved? Evidence from mouse and rat, Chromosoma 97 (1989) 459-464.

[18] Eldridge M.D., Johnston P.G., Chromosomal rearrangements in rock wallabies, Petrogale (Marsupialia: Macropodidae). VIII. An investigation of the nonrandom nature of karyotypic change, Genome 36 (1993) 524-534.

[19] Fundia A.F., Mudry M., Inducción de sitios frágiles en Cebus apella, Bol. Primatol. Arg. 5 (1987) 7-12.

[20] Fundia A.F., Larripa I.B., Coincidence in fragile site expression with fluorodeoxyuridine and bromodeoxyuridine, Cancer Genet. Cytogenet. 41 (1989) 41-48.

[21] Fundia A.F., Gorostiaga M.A., Delprat A., Mudry M., Fragile sites analysis and definition of chromosome landmarks, bands and regions in Alouatta caraya (ACA), in: Akiyoshi Ehara et al. (Eds.), Primatology Today, Elsevier Science Publishers B.V. (Biomedical Division), 1991, pp. 617-618.

[22] Fundia A.F., Gorostiaga M.A., Hick A., Mudry M., Fragile site (FS) expression in Cebidae (Primates: Platyrrhini), Chromosome Research 3 (1995) 74.

[23] Fundia A., Giere I., Larripa I., Slavutsky I., Spontaneous breakage and fragile site expression in chronic lymphocytic leukemia, Cancer Genet. Cytogenet. 103 (1998) 144-148.

[24] Furuya T., Ochi H., Watanabe S., Common fragile sites in chromosomes of bone marrow cells and peripheral blood lymphocytes from healthy persons and leukemia patients, Cancer Genet. Cytogenet. 43 (1989) 131-138.

[25] García M., Borrell A., Mudry M., Egozcue J., Ponsà M., Prometaphase karyotype and restriction enzymes banding (REs) in squirrel monkeys: Saimiri boliviensis boliviensis (Primates: Platyrrhini), J. Mammal. 76 (1995) 497-503.

[26] Glover T.W., Instability at chromosomal fragile sites, Recent Results Cancer Res. 154 (1998) 185-199.

[27] Glover T.W., Berger C., Coyle J., Echo B., DNA polymerase $\alpha$ inhibition by aphidicolin induces gaps snd breaks at common fragile sites in human chromosomes, Hum. Genet. 67 (1984) 136-142.

[28] Guichaoua M., Mattei M.G., Mattei J.F., Girand F., Aspects génétiques des sites fragiles autosomiques. A propos de 40 cas, J. Génét. Hum. 30 (1982) 183-197.

[29] ISCN An International system for human cytogenetic nomenclature (1995), Mitelman F. (Ed.), Published in collaboration with Cytogenet. Cell Genet. S. Karger, Basel, 1995, pp. 1-114. 
[30] John B., Chromosome change and evolutionary change: a critique, in: Azhley W.R. and Woodniff D.S. (Eds.) Evolution and speciation: Essays in Honor of M.J.D. White, New York, Cambridge University Press, 1981, pp. 23-51.

[31] Jotterand Bellomo M., Les sites fragiles autosomiques, J. Génét. Hum. 32 (1984) 155-166.

[32] Lau Y.F., Arrighi F.E., Studies of the squirrel monkey, Saimiri sciureus genome. I. Cytological characterization of chromosomal heterozygosity, Cytogenet. Cell Genet. 17 (1976) 51-60.

[33] Le Beau M.M., Chromosomal fragile sites and cancer specific breakpoints. A moderating viewpoint, Cancer Genet. Cytogenet. 31 (1988) 55-62.

[34] Lin M.S., Takabayashi T., Wilson M.G., Marchese C.A., An in vitro and in vivo study of a BrdU- sensitive fragile site in the Chinese hamster, Cytogenet. Cell Genet. 38 (1984) 211-215.

[35] Ma N.S.F., Jones T.C., Added heterochromatin segments in chromosomes of squirrel monkeys (Saimiri sciureus), Folia Primatol. 24 (1975) 282-292.

[36] Ma N.S.F., Jones T.C., Thorrington R.W., Cooper R.W., Chromosome banding patterns in squirrel monkeys, J. Medical Primatol. 3 (1974) 120-137.

[37] Matayoshi T., Seuanez H.N., Nasazzi N., Nagle C., Armada J.L., Freitas L., Alves G., Barroso C.M., Howlin E., Heterochromatic variation in Cebus apella (Cebidae, Platyrrhini) of different geographic regions, Cytogenet. Cell Genet. 44 (1987) $158-162$.

[38] Mc Allister B.F., Greenbaum I.F., How common are common fragile sites: variation of aphidicolin- induced chromosomal fragile sites in a population of the deer mouse (Peromyscus maniculatus), Hum. Genet. 100 (1997) 182-188.

[39] Miró R., Clemente I.C., Fuster C., Egozcue J., Fragile sites, chromosome evolution and human neoplasia, Hum. Genet. 75 (1987) 345-369.

[40] Moore C.M., Harris C.P., Abel C.R., Distribution of chromosomal polymorphism in three subspecies of squirrel monkeys (genus Saimiri), Cytogenet. Cell Genet. 53 (1990) 118-122.

[41] Mudry M.D., Cytogenetic variability within and across populations of Cebus apella in Argentina, Folia Primatol. 54 (1990) 206-216.

[42] Mudry de Pargament M., Slavutsky I., Banding patterns of the chromosomes of Cebus apella: Comparative studies between specimens from Paraguay and Argentina, Primates 28 (1987) 111-117.

[43] Mudry M., Slavutsky I., Labal de Vinuesa M., Chromosome comparison among five species of Platyrrhini (Alouatta caraya, Aotus azarae, Callithrix jacchus, Cebus apella and Saimiri sciureus), Primates 31 (1990) 415-420.

[44] Mudry M., Slavutsky I., Zunino G., Delprat A., Brown A., A new karyotype of Cebus apella from Argentina, Rev. Bras. Genet. 14 (1991) 729-738.

[45] Mudry M., Ponsà M., Borrell A., Egozcue J., García M., Prometaphase chromosome of the Howler monkey (Alouatta caraya): G, C, NOR and restriction enzyme (REs) banding, Am. J. Primatol. 33 (1994) 121-132.

[46] Mudry M., Fundia A., Hick A., Gorostiaga M., Labilidad cromosómica: una posible explicación en el origen de los reordenamientos cromosómicos en Cébidos, Bol. Primatol. Lat. 5 (1995) 7-15.

[47] Mudry M.D., Rahn M., Gorostiaga M., Hick A., Merani M.S., Solari A.J., Revised karyotype of Alouatta caraya (Primates: Platyrrhini) based on synaptonemal complex and banding analyses, Hereditas 128 (1998) 9-16.

[48] Nickerson E., Nelson D.L., Molecular definition of pericentric inversion breakpoints occurring during the evolution of humans and chimpanzees, Genomics 50 (1998) 368-372.

[49] Pennisi E., New gene forges link between fragile site and many cancers, Science 272 (1996) 649. 
[50] Ponsá M., García M., Borrell A., García F., Egozcue J., Gorostiaga M., Delprat A., Mudry M., Heterochromatin and cytogenetic polimorphisms in Cebus apella (Cebidae: Platyrrhini), Am. J. Primatol. 37 (1995) 325-331.

[51] Qumsiyeh M.B., Baker R.J., Comparative cytogenetics and the determination of primitive karyotypes, Cytogenet. Cell Genet. 47 (1988) 100-103.

[52] Rahn M.I., Mudry M., Merani M.S., Solari A.J., Meiotic behavior of the X1X2Y1Y2 quadrivalent of the primate Alouatta caraya, Chromosome Res. 4 (1996) 350-356.

[53] Richard F., Lombard M., Dutrillaux B., ZOO-FISH suggests a complete homology between human and Capuchin Monkey (Platyrrhini) euchromatin, Genomics 86 (1996) 417-423.

[54] Rønne M., Putative fragile sites in the horse karyotype, Hereditas 117 (1992) $127-136$.

[55] Rønne M., Localization of fragile sites in the karyotype of Felis catus, Hereditas 122 (1995) 279-283.

[56] Rфnne M., Localization of fragile sites in the karyotype of Sus scrofa domestica: Present status, Hereditas 122 (1995) 153-162.

[57] Samonte R.V., Conte R.A., Verma R.S., Localization of human midisatellite and macrosatellite DNA sequences on chromosomes 1 and $\mathrm{X}$ in the great apes, J. Hum. Genet. 44 (1999) 57-59.

[58] Schmid M., Ott G., Haaf T., Scheres J.M.J.C., Evolutionary conservation of fragile sites induced by 5 - azacytidine and 5-azadeoxy-cytidine in man, gorilla and chimpanzee, Hum. Genet. 71 (1985) 342-350.

[59] Seabright M., A Rapid banding technique for human chromosome, Lancet 2 (1971) 971-972.

[60] Smeets D.F.C.N., Klundert F.A.J.M., Common fragile sites in man and 3 closely related primate species, Cytogenet. Cell Genet. 53 (1990) 8-14.

[61] Smith D.I., Huang H., Wang L., Common fragile sites and cancer, Int. J. Oncol. 12 (1998) 187-196.

[62] Stone D.M., Stephens K.E., Bromodeoxyuridine induces chromosomal fragile sites in the canine genome, Am. J. Med. Genet. 46 (1993) 198-202.

[63] Sutherland G.R., Baker E., Richards R.I., Fragile sites still breaking, TIG 14 (1998) 501-506.

[64] Uchida I.A., Freeman U.C.P., Basrur P.K., The fragile X in cattle, Am. J. Med. Genet. 23 (1986) 557-562.

[65] Vassart M., Guédant A., Vié J.C., Kéravec J., Séguéla A., Volobouev V.T., Chromosomes of Alouatta seniculus (Platyrrhini, Primates) from French Guiana, J. Hered. 87 (1996) 331-334.

[66] Verma R.S., Heterochromatin. Molecular and structural aspects, Ed. Cambridge University Press, 1988, pp. 44-61.

[67] von Dornum M., Ruvolo M., Phylogenetic relationships of the New World Monkeys (Primates, Platyrrhini) based on nuclear G6PD DNA sequences, Mol. Phylogenet. Evol. 11 (1999) 459-476.

[68] Wienberg J., Stanyon R., Comparative painting of mammalian chromosomes, Curr. Opin. Genet. Dev. 7 (1997) 784-791.

[69] Wurster-Hill D.H., Ward O.G., Davis B.H., Park J.P., Moyzis R.K., Meyne J., Fragile sites, telomeric DNA sequences, B chromosomes and DNA content in raccoon dogs, Nyctereutes procyonoides, with comparative notttes on foxes, coyote, wolf and raccon, Cytogenet. Cell Genet. 49 (1988) 278-281.

[70] Yunis J.J., Soreng L., Constitutive fragile sites and cancer, Science 226 (1984) 1199-1204.

[71] Yunis J.J., Soreng A.L., Bowe A.E., Fragile sites are targets of diverse mutagens and carcinogens, Oncogene 1 (1987) 59-69. 